\title{
EVALUATION OF DISCHARGE REGULATION IN GATED PIPE IRRIGATION ALONG LINE
}

\author{
M. N. El Awady' ${ }^{1}$ S. A. Tayel' ${ }^{2}$ H. A. A. El Mawla ${ }^{3}$, A. M. El Lithy \\ and A. M. Mahmoud ${ }^{5}$
}

\begin{abstract}
The experimental field work, carried out on the design of gated pipes system for testing, was locally made in the workshop in Esna village, Esna city, Qena Governorate. The main objective of the experimental field work was carried out in field to study the performance of gated pipe system tested to determine the head and discharge along gated pipeline. The flow variation was investigated through 30 meter long pipe of 160 mm outside diameter, with closed end having 40 gated pipes of $38 \mathrm{~mm}$ diameter. The orifice can be closed by sliding gate to about $46.6 \%$.

Therefore, the discharge regulation of flow through orifices along the gated pipes was about $53.4 \%$.
\end{abstract}

\section{INTRODUCTION}

$\mathrm{E}$ gypt has a high population density and is an agricultural country. Agricultural irrigation technologies play important role in supporting national economy.

Surface irrigation is the oldest and most widely used method of Egypt irrigation. At least from 4000 years ago, surface irrigation comprised: basin, border or furrows. This is due to its low capital maintenance costs and low energy requirements. Among the many irrigation methods, the traditional method of surface irrigation is inefficient with conveyance water losses through runoff, deep percolation and evaporation from farm

- Prof. Emt. of Agric. Eng., Fac. Agric., Ain Shams Univ. ${ }^{1}$

- Prof. Emt. of Agric. Eng., Fac. Agric., AL-Azhar Univ. ${ }^{2}$

- Prof. of Agric. Eng., Fac. Agric., AL-Azhar Univ., Assiut. ${ }^{3}$

- Assoc. Prof. of Agric. Eng., Fac. Agric., AL-Azhar Univ., Assiut. ${ }^{4}$

- Agric. Eng., Fac. Agric., AL-Azhar Univ., Assiut. ${ }^{5}$ 
canals. Surface irrigation development is essential to raise efficiency and save a lot of water quantity and obtain the highest crop yield.

Gated pipe irrigation is a type of furrow irrigation in which conventional head ditch and siphons are replaced by an above-ground pipeline. Irrigation water flows from orifices (gates) which are regularly spaced along the pipeline. Currently, there are several brands or types of gated pipes. Little data are available from the manufacturers on their performance. Furthermore, the technical literature contains little information on the design of gated pipe systems. Smith et al. (1986).

The irrigation can increase the uniformity of application of water to furrow irrigation of crops by frequent regulation of the size of stream flowing into the furrow. For this purpose, gated system was suggested specially to be helpful. Small and easily adjusted gates in the pipe facilitate controlling the size of the stream to furrow as small as $0.1 \mathrm{~L} / \mathrm{s}$ or as large as $1.0 \mathrm{~L} / \mathrm{s}$. Rates of flow are changed by altering the size of outlets, varying the number of outlets or changing of the operating head. Adjustable gated orifices minimize the effect of pressure head differentials on discharge rate, Jensen (1980).

El Berry et al.(2006) concluded that the priority is given to use the developed surface irrigation systems in large areas with less field length to get the maximum benefit from:

1- Low capital investments used for execution, to cover more area.

2- Saved areas which were occupied by channels and ridges.

3- The reduction in the amount of irrigation water per Fadden, and consequently in increased saving in water losses.

4- More saved area which occupies the channels and ridges, controlling the lengths of the fields.

They applied the system to enlarge the amount of applied water savings. Jensen (1980) reported that the expression of evaluating uniformity distribution through the variation of flow through orifices along the lateral is line named flow variation along the lateral line " qvar ". The uniformity distribution increased as variation decreased. 


$$
\mathrm{q}_{\mathrm{var}}=\mathrm{q}_{\max }-\mathrm{q}_{\min } / \mathrm{q}_{\max }
$$

where:

$\mathrm{q}_{\mathrm{var}}=$ the orifice flow variation $\%, \mathrm{q}_{\max }=$ the maximum orifice flow along the lateral line, $\mathrm{L} / \mathrm{s}$ and, $\mathrm{q}_{\min }=$ the minimum orifice flow along the lateral line, L/s.

Humpherys (1986) found that gated pipe is one of the techniques where water flow could be controlled for better uniformity and efficiency. The gated pipelines installed in a series of level sections at both the upper end and middle of the field.

The gated pipe has many advantages, Hassan (1990):

1- Reduced seepage and evaporation losses. 2- Less land taken up by the irrigation system 3- Can improve public health by avoiding contact with infected water. 4- Reduced maintenance requirements. 5- Better control over water distribution. 6- Eliminate ditch bank weed problems.

Li et al. (1998) noted that the gated pipe irrigation method of distributing water to a field by gated pipeline censes a reduction in land losses to ditches. Osman et al. (2005) indicated that irrigation requirements using gated pipe system is better than traditional irrigation method. Gated pipes irrigation system saves $(19.81 \%)$ compared to traditional irrigation method. Abo Soliman et al. (2005) indicated that the irrigation by gated pipe achieved the highest values of yield and saved amount of irrigation water applied by $11.9 \%$.

Rady (1993) found that by using gated pipe to irrigate long furrow (100 $\mathrm{m}$ long) resulted in saving water by $20 \%, 38 \%$ and $18 \%$ and increasing the water use efficiency by $58 \%, 26 \%$ and $17 \%$ for beans, corn and peas respectively, compared with conventional surface irrigation method used short furrows (6-10 m long) in sandy soil.

Kincaid and Kemper (1982) described the hydraulic analysis of the gated pipe irrigation system. The friction losses are computed based on full pipe flow and the energy equation is used to determine the difference in piezometric head, between two adjacent orifices. The piezometric head is measured from the center of the orifices. El Sayed (1998) concluded that the discharge rate through the opening increased as the pressure head of the opening increases. Also by increasing the flow velocity of water inside the pipe, the discharge of the opening increases. The coefficient of The $16^{\text {th }}$. Annual Conference of the Misr Society of Ag. Eng., 25 July, 2009 
discharge of the opening decreased as the discharge rate of the gate increased.

Arora (1976) showed that the value of the coefficient of discharge for sharp edged orifice ranges from 0.59 to 0.68 . Its value depends upon the coefficients of velocity and contraction. Kincold and Kemper(1982), Lewitt (1963) and Massey (1990) stated that the value of the coefficient of discharge is between 0.60 and 0.65 .

El Awady et al. (2002) noticed that the measured "h" dropped slightly in the first portion of the gated pipe and this dropping ended near $21.0 \%$ of gated pipe length, because the cumulative friction head losses were greater than superimposed pressure head " $h$ " and thus overcomes its effect. After that, the measured pressure head increased gradually until it reached the pipe end at about $96 \%$ of the original pressure head at the gated pipe inlet, because the gradual increase in "h" overcomes the effects of the cumulative friction head losses.

El Sayed (1998) noted that the flow through gated orifice decreased the velocity of water downstream of the flow. Consequently a pressure head is generated through the pipe. As the velocity reached zero at the closed valve (at the end of the pipe), the highest value of pressure head was obtained. Also, there is increase in flow discharge rate of pumping unit, both of the superimposed head and expected head at the end of the pipe. Smith et al. (1986) stated that measuring gated pipe uniformity is required, so that the effect of the variation of particular parameter on outflow uniformity can be quantified. The measure of variability selected was the range of the outflows, which is defined as the difference between the maximum and minimum outflows along the pipeline, expressed as a percentage of the mean outflow.

El-Yazal et al. (2002) showed that the flow variation through 12 meters spacing of the perforated piping system was about 5.3\%. Therefore, the uniformity distribution of flow through orifices along the perforated pipes was about 94.7\%. Zimmerman (1966) reported that aluminum or galvanized iron gated pipes are the costliest of all the types of gated pipe. Li et al. (1998) indicated that the economic analysis PVC gated pipe system has lower investment and higher irrigation efficiency. 


\section{MATERIALS AND METHODS}

The main objective of this research is to study the performance of gated pipe system, tested to determine the head and discharge along gated pipeline. The field experimental work was carried out in Esna village, Esna city, Qena Governorate(إسنا، محافظة_قنا). The main task of the experimental work was to study the performance of gated pipe system, tested to determine the head and discharge along gated pipeline.

Table (1): The specification of the pumping unit.

\begin{tabular}{|c|c|c|c|c|c|c|}
\hline $\begin{array}{c}\text { Type of } \\
\text { pump }\end{array}$ & $\begin{array}{c}\text { Pump } \\
\text { made }\end{array}$ & $\begin{array}{c}\text { Motor } \\
\text { Power } \\
(\mathrm{Hp})\end{array}$ & $\mathrm{rpm}$ & $\begin{array}{c}\text { Max. } \\
\text { discharge } \\
\left(\mathrm{m}^{3} / \mathrm{h}\right)\end{array}$ & $\begin{array}{c}\text { Suction } \\
\text { pipe } \\
\text { diameter } \\
(\mathrm{mm})\end{array}$ & $\begin{array}{c}\text { Delivery } \\
\text { pipe } \\
\text { diameter } \\
(\mathrm{mm})\end{array}$ \\
\hline $\begin{array}{c}\text { Centrifugal } \\
\text {-Diesel }\end{array}$ & $\begin{array}{c}\text { Al- } \\
\text { Weiler }\end{array}$ & 15.6 & 1450 & 120 & 160 & 160 \\
\hline
\end{tabular}

The design of gated pipes system for testing on field was locally manufactured in the workshop in Esna village, Esna city, Qena Governorate. They were manufactured using "5" pipes $160 \mathrm{~mm}$. The connecting pipes, elbows, and fittings for the pumping unit were also locally manufactured, and the system was equipped with the required valves, flow meter, and pressure gauge. A 30 meter long pipe of $160 \mathrm{~mm}$ outside diameter, with closed end having 40 gated pipes of $38 \mathrm{~mm}$ diameter was drilled. The orifice can be closed by sliding gate in order to enable testing the performance of any number of operating orifices, to give number of gates 40 (30 meter), as shown in Fig.(1).

The actual performance of the gated pipe system was tested by measuring the gates flow rate along the gated pipe under actual field operating conditions. From the experimentally measured pressure head at entrance and end of pipe, the discharge of each outlet, the superimposed pressure head ware estimated and graphically expressed.

The experimental field measurements 


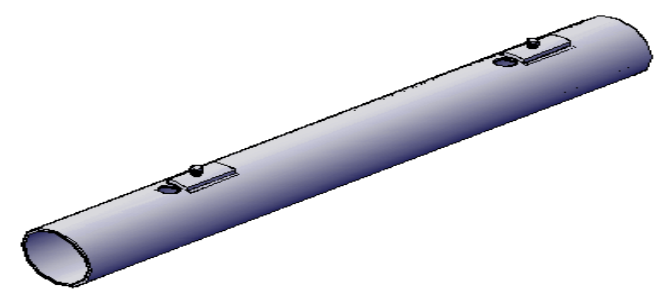

Isometric of gated pipe.
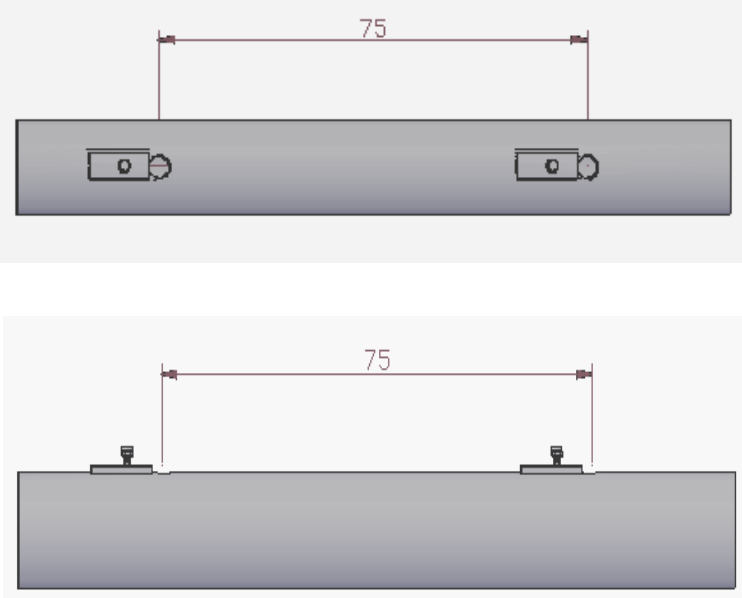

Section of gated pipeline distance between of the gates $(\mathrm{cm})$.

(Dims are in $\mathrm{m}$ ).

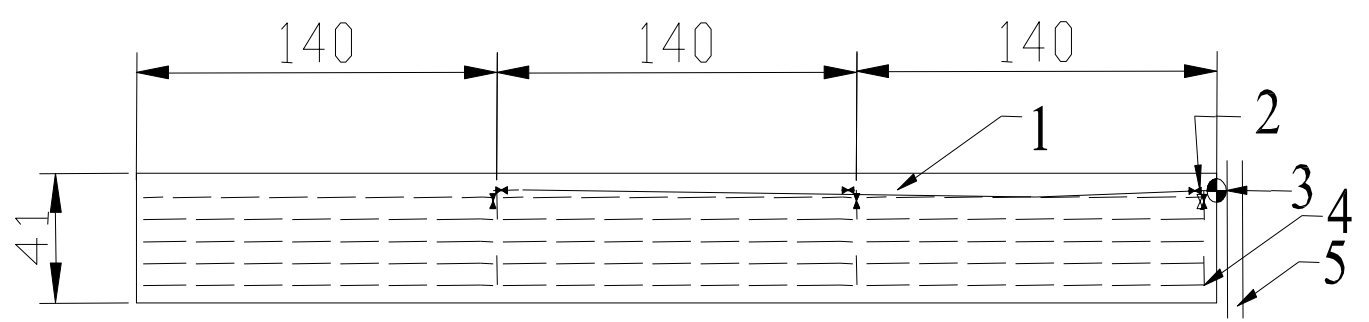

1-Main line 2-Valve 3-Pump

4-Gates line 5-Canal

Fig.(1):A typical installation of gated pipe irrigation system in Isna. 


\section{a) Discharge rate:}

The gated pipe system was tested by measuring the gate flow rate along the gated pipe under actual field operating conditions by direct method using a bucket and stop watch.

\section{b) Stop watch:}

Whenever time was concerned. A stop watch was used to measure the consumed time in different operations. The accuracy of the stop watch (Chinese manufacture) was 1/60 of a second.

\section{C) Pressure head:}

The pressure head was measured by a piezometre at the center of the gate.

\section{D) Piezometric tube:}

The tube was made from plastic locally manufactured using 1" In inside diameter connected with graduated scale.

\section{RESULTS AND DISCUSSION}

The results and discussion cover the following:

The field experimental works carried out in field to study the performance of gated pipe system as tested to determine head, discharge and discharge coefficient along gated pipeline.

The performance of gated pipe system in field was tested to determine the actual and theoretical discharge rate, discharge coefficient and pressure head along gated pipeline.

The results of the computation and measurements for orifice discharge are shown in graphically in Figures (1), (2) and (3).

The data showed that the range of pressure head was from $10 \mathrm{~cm}$ to 65 $\mathrm{cm}$. It dropped gradually in the gated pipe and this dropping trend ended. After that, the measured pressure head increased gradually until it reached pipe end.

The relationship between pressure head and the gate number on the pipeline decreased to the $31 \underline{\mathrm{st}}$. and increased to the end of pipeline. It was $65 \mathrm{~cm}$ at first gate and decreased to $10 \mathrm{~cm}$ at 31 st. gated pipe. After that, the pressure head increased from $15 \mathrm{~cm}$ at 32 nd. gated pipe to $27 \mathrm{~cm}$ at the number of gated pipe 40 which was at the end of pipeline. 


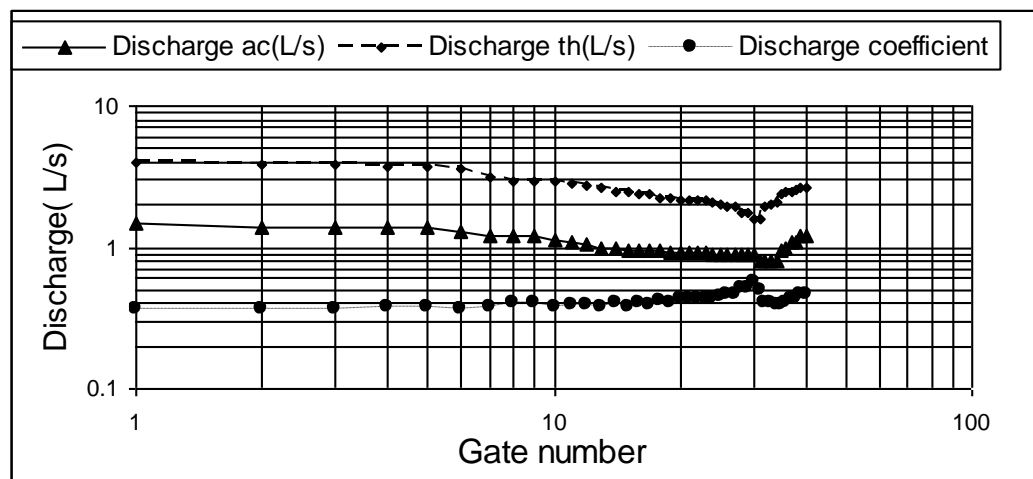

Fig.(1): Relation between the discharge L/s and gate number at along line

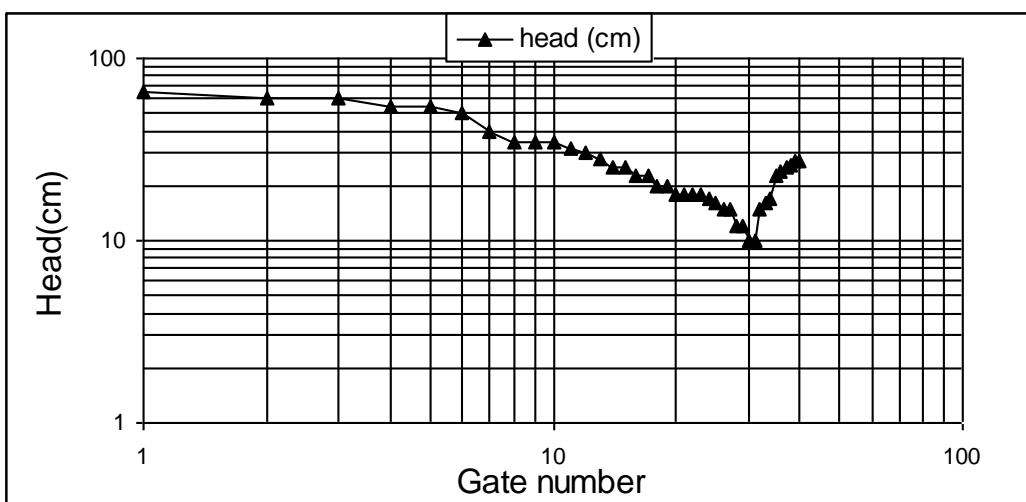

Fig.(2): Relation between the head $(\mathrm{cm})$ and gate number at along line

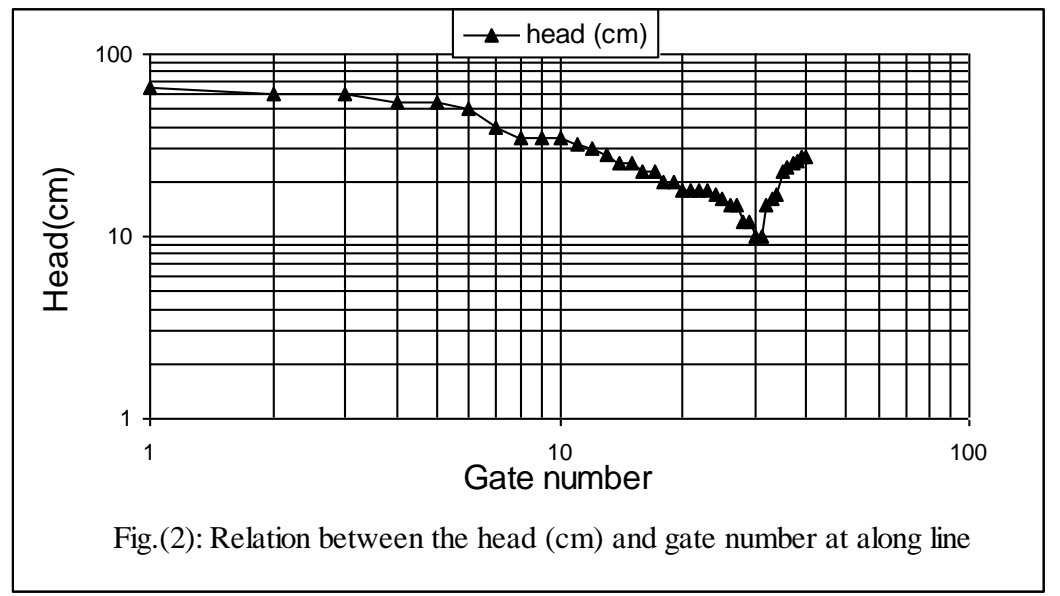

The $16^{\text {th }}$. Annual Conference of the Misr Society of Ag. Eng., 25 July, 2009 
The results of gates actual discharge decreased to the 34 th. and increased to the end of pipeline. It was $1.5 \mathrm{~L} / \mathrm{s}$ at first gate and decreased

to $0.8 \mathrm{~L} / \mathrm{s}$ at 34 th. gated pipe. After that, the discharge rate increased from $0.95 \mathrm{~L} / \mathrm{s}$ at 35 th. gated pipe to $1.2 \mathrm{~L} / \mathrm{s}$ at the number of gated pipe 40 which was at the end of pipeline.

Also, the results of theoretical discharge of gates decreasedto the 32 th. and increased to the end of pipeline. It was $4.05 \mathrm{~L} / \mathrm{s}$ at first gate and decreased to $1.94 \mathrm{~L} / \mathrm{s}$ at 32 th. gated pipe. After that, the discharge rate increased from $2.1 \mathrm{~L} / \mathrm{s}$ at $33 \mathrm{th}$. gated pipe to $2.61 \mathrm{~L} / \mathrm{s}$ at the number of gated pipe 40 which was at the end of pipeline.

Gated pipe discharge dropped, due to friction head losses then there was a gradual increase in it due to the increase in pressure head which counteracted the effect of friction head losses.

The variation between the maximum discharge and the minimum discharge along gated pipeline calculated from equation (1), was about $46.6 \%$. Therefore the discharge regulation outlet the gates along gated pipeline was about $53.4 \%$.

The coefficient of discharge decreased as the pressure head of gated orifice and of superimposed head increased. Rates from the tested gates ranged between 0.57 to 0.36 . The coefficient of discharge ranged between 0.36 for the gates at the start of the pipe, then tended to increase till 0.57 at nearly $22 \mathrm{~m}$ of the pipe length $(30 \mathrm{~m}), 0.46$ through the pipe end.

\section{CONCLOSION}

1- The relationship between pressure head and the discharge rate of gated pipes system decreased under experimental field conditions. Head dropped gradually in the gated pipe then it the discharge rate increased at the end of pipeline.

2- The variation between the maximum and minimum discharges along gated pipeline was about $46.6 \%$. Therefore, the discharge regulation of gates along gated pipeline was about $53.4 \%$, which was relatively less than other values found in literature. 


\section{REFERENCES}

Abo soliman M. S. M, H. E. Osman, M. M. Said and E. H.Omar (2005) maiza,barley production and water use efficiency as influenced by different irrigation methods in Egyptian old land $.13^{\text {th }}$ Ann. Conf. of. Misr Soc. Agric. Eng., 14-15 Dec,: 1-22.

Arora, K. R. (1976). Fluid mechanics and hydraulic machines, B, NAT. SAAK-Delhi,:1169.

El Awady, M. N., M. T. El Tantawy, S. S. Hassan and A. O. M. EIAshhab (2002). Water-flow uniformity distribution through irrigation gated Pipes, Misr J. Ag. Eng. 19 (3) : 677 - 690.

El Berry, A. M., F. G. Ebaby, S. S. Hassan and S. M. Fattouh (2006). Performance of locally developed surface irrigation in sugar cans production. Misr J. Agric. Eng., 23(1):169-19.

El Sayed, G. H. (1998). Hyardic studies for gated pipe distribution system. Egypt. J. Agric. Res., 76 (1): 387 - 403.

El Yazal, M. N., S. S. Hassan and M. T. El-Tantawy (2002). Effect of land leveling on maize crop under perforated irrigation pipes in old land. Misr J. Ag. Eng., 19 (2):437-454.

Hassan, S. S. A. (1990). The performance of perforated tubes for surface irrigation in small holdings in Egypt. M. Sc. Thesis, Agric. Eng. Dept., Fac. of Agric., Cairo Univ., Eg.

Hassan, S. S. (1998). Engineering studies for increasing water distribution uniformity of perforated pipes for surface irrigation system. Ph.D. Thesis, Agric. Eng. Dept., Fac. of Agric., Cairo Univ., Egypt.

Humphreys, A. S. (1986). Automated farm surface irrigation system world wide. Special publ., ICID, New Delhi, India.

Jenesn, M. E. (1980): Design and operation of farm irrigation system. ASAE:, Monogr. 3, ASAE. St, Joseph, MI,:829.

Jipin, Li (1998). Evaluation of gated pipe basin irrigation method in China conf. ASAE I. Mtg., or Land, Fl. USA: 11-16.

Kncaid, D, C. and W- D. Kemper (1982). Cablegation: 11. Simulation and design of the moving plug gated pipe irrigation system. Trans, of the ASAE $25: 388$ - 395, 
Lewitt. E. H. (1963). Hydraulic of fluid mechanics. PIT, Man and Sons. Ltd. SIR: 752. (C. F. Hassan, 1998)

Massey, B. S. (1990). Mechanics of fluid. Pub, by Van N-ostarnd, Reinhold (U.K) Co, - Ltd, Molly Millars Lane, Works, Berk, Engi. : 625 pp. (C. F. Hassan, 1990)

Osman, H. E., H. S. Mehawed and A. A. Abdel-Aziz (2005) Using modified surface irrigation in old land mango farm in Nile valley, watershed management to meet water quality standards and emerging, TMDL(total maximum daily load), 3rd Conf.,March,5-9 ${ }^{\text {th }}$, 20701P0705,ASAE, Atlanta, Georgia, USA.

Rady, M. Abdel-Hady (1993). Project evaluation of irrigation system on sandy and calcareous soils ASRT, Cairo.

Smith. R. J., P. J. Watts and S. J. Mulder (1986) Analysis and design of gated irrigation pipelines. Agric. water mang. (12): 99-115.

Zinimerman, H. D. (1966) Irrigation. John Wileys sons, Inc, MY.,: 522. (C. F, EL Sayed, 1998)

الملخص العربى

\section{تقييم انتظام الرى بالبوابات على طول الخط}

محمد نبيل العوضى' سمير احمد طايل` حسن عبد الرازق عبد المولى احمد ماهر الليثى؛

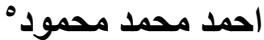

أجريت هذه التجربة فى مركز سنا محافظة قنا بهدف تقيم أداء نظام الرى الحقلى بالبوابات

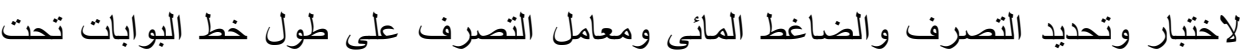

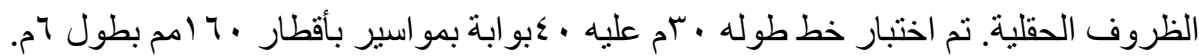

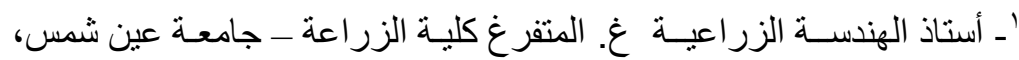

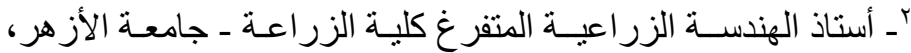

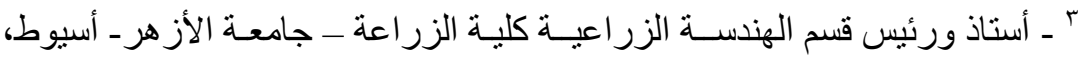

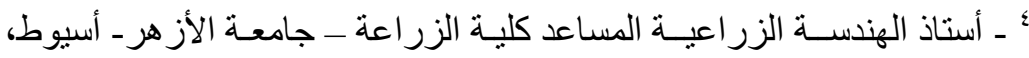

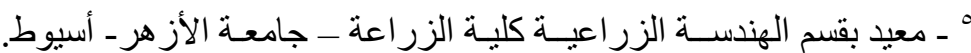

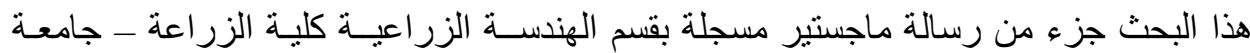
الأز هر ـ أسيوط تحت إنشر اف لجنة الإشر اف المشار إليها سابقا. The $16^{\text {th }}$. Annual Conference of the Misr Society of Ag. Eng., 25 July, 2009 


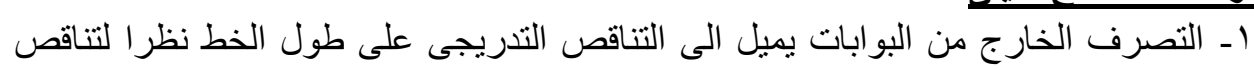

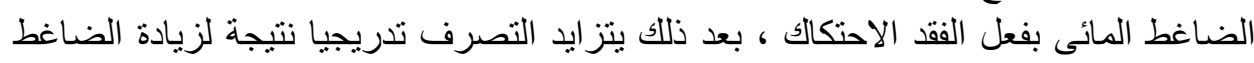

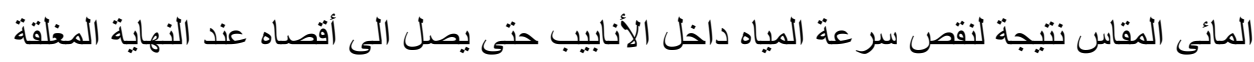

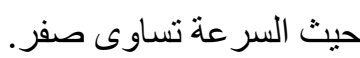

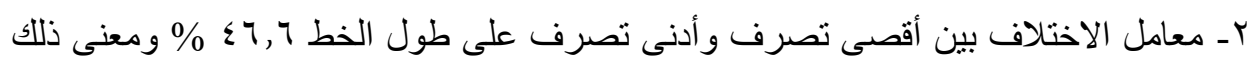

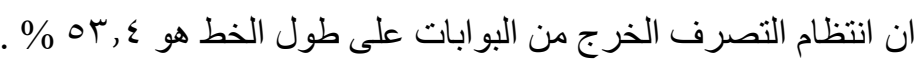

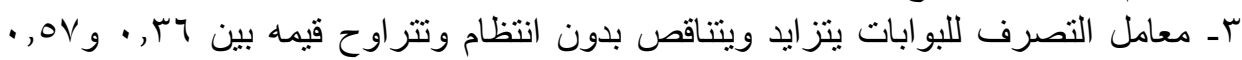

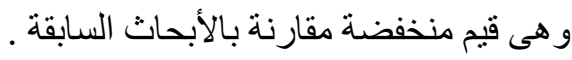

